\title{
Structural and Spectral Features of Selenium Nanospheres Produced by Se-Respiring Bacteria
}

\author{
Ronald S. Oremland, ${ }^{1 *}$ Mitchell J. Herbel, ${ }^{1} \dagger$ Jodi Switzer Blum, ${ }^{1}$ Sean Langley, ${ }^{2}$ \\ Terry J. Beveridge, ${ }^{2}$ Pulickel M. Ajayan, ${ }^{3}$ Thomas Sutto, ${ }^{4}$ Amanda V. Ellis, ${ }^{5}$ \\ and Seamus Curran ${ }^{5}$ \\ Water Resources Division, U.S. Geological Survey, Menlo Park, California 94025'; Department of Microbiology, College of \\ Biological Science, University of Guelph, Guelph, Ontario, Canada N1G 2W12; Department of Materials Sciences, \\ Rensselaer Polytechnic Institute, Troy, New York 1218033; Chemistry Division, Naval Surface Warfare Center, \\ Dahlgren, Virginia 224484; and Physics Department, New Mexico State University, Las Cruces, \\ New Mexico $88001^{5}$
}

Received 29 July 2003/Accepted 8 October 2003

\begin{abstract}
Certain anaerobic bacteria respire toxic selenium oxyanions and in doing so produce extracellular accumulations of elemental selenium [Se(0)]. We examined three physiologically and phylogenetically diverse species of selenate- and selenite-respiring bacteria, Sulfurospirillum barnesii, Bacillus selenitireducens, and Selenihalanaerobacter shriftii, for the occurrence of this phenomenon. When grown with selenium oxyanions as the electron acceptor, all of these organisms formed extracellular granules consisting of stable, uniform nanospheres (diameter, $\sim 300 \mathrm{~nm}$ ) of $\operatorname{Se}(\mathbf{0})$ having monoclinic crystalline structures. Intracellular packets of $\operatorname{Se}(\mathbf{0})$ were also noted. The number of intracellular $\mathrm{Se}(0)$ packets could be reduced by first growing cells with nitrate as the electron acceptor and then adding selenite ions to washed suspensions of the nitrate-grown cells. This resulted in the formation of primarily extracellular Se nanospheres. After harvesting and cleansing of cellular debris, we observed large differences in the optical properties (UV-visible absorption and Raman spectra) of purified extracellular nanospheres produced in this manner by the three different bacterial species. The spectral properties in turn differed substantially from those of amorphous $\mathrm{Se}(0)$ formed by chemical oxidation of $\mathrm{H}_{2} \mathrm{Se}$ and of black, vitreous $\mathrm{Se}(\mathrm{0})$ formed chemically by reduction of selenite with ascorbate. The microbial synthesis of $\mathrm{Se}(\mathbf{0})$ nanospheres results in unique, complex, compacted nanostructural arrangements of $\mathrm{Se}$ atoms. These arrangements probably reflect a diversity of enzymes involved in the dissimilatory reduction that are subtly different in different microbes. Remarkably, these conditions cannot be achieved by current methods of chemical synthesis.
\end{abstract}

Selenium is a metalloid element that is chemically similar to sulfur and tellurium and in nature exists in four oxidation states, $-2,0,+4$, and +6 . The last two states occur in aqueous media as the soluble oxyanions selenite $\left[\mathrm{SeO}_{3}{ }^{2-}\right.$ or $\left.\mathrm{Se}(\mathrm{IV})\right]$ and selenate $\left[\mathrm{SeO}_{4}{ }^{2-}\right.$ or $\left.\mathrm{Se}(\mathrm{VI})\right]$. Selenium also has unusual photo-optical and semiconducting physical properties and has industrial applications in devices such as photocopiers and microelectronic circuits. Recent interest in the field of nanotechnology has stimulated research into the chemical synthesis of selenium nanowires that are composed of elemental selenium $[\mathrm{Se}(0)](1,10,11)$. However, the various allotropes of $\mathrm{Se}(0)$ are not well understood in terms of the internal structural arrangements of the selenium atoms, and hence selenium still is a complex element in terms of our understanding of its fundamental physical properties (3).

In biology, selenium is a key trace element that is found in representative species from all three domains of life (Bacteria, Archaea, and Eukaryota), as well as in viruses (34). At the molecular level, Se occurs in analogs of sulfur-containing amino acids (e.g., selenomethionine, selenocysteine) and is

\footnotetext{
* Corresponding author. Mailing address: U.S. Geological Survey, ms 480, 345 Middlefield Rd., Menlo Park, CA 94025. Phone: (650) 329-4482. Fax: (650) 329-4463. E-mail: roremlan@usgs.gov.

† Present address: Department of Geology \& Earth Sciences, Stanford University, Stanford, CA 94305.
}

found in diverse enzymes $(14,37)$. Selenocysteine is an essential component of the geometry and corresponding electron density of certain enzymatic active sites, such as those of formate dehydrogenase (2). Ironically, although selenium is considered an essential dietary trace element, high concentrations of it are acutely toxic. Hydrologic changes in naturally seleniferous regions have caused serious environmental problems, notably in the western San Joaquin Valley of California (32). Selenium has a complete biogeochemical cycle in nature, with microbial redox reactions leading both to and from all of its oxidation states $(7,15)$. An important component of this cycle is the dissimilatory (respiratory) reduction of selenate and selenite to $\mathrm{Se}(0)$ in reactions that are catalyzed by anaerobic microorganisms inhabiting anoxic sediments $(26,27,38)$.

To date, about 16 diverse species of Bacteria and Archaea have been described that grow anaerobically by linking the oxidation of organic substrates or $\mathrm{H}_{2}$ to the dissimilatory reduction of selenium oxyanions $(30,39)$. The end products of these reactions are the red, amorphous or monoclinic allotropes of $\mathrm{Se}(0)$, which accumulate in spent medium because the microorganisms reduce the 10 to $20 \mathrm{mM}$ selenate or selenite provided to $\mathrm{Se}(0)$. Respiratory reductases for Se oxyanions contain molybdenum and are associated with the plasma membrane (18). In contrast, Se-resistant bacteria typically tolerate exposure to $\leq 1 \mathrm{mM}$ selenite or $\leq 1 \mathrm{mM}$ selenate, which they also reduce to $\mathrm{Se}(0)$ and excrete as distinct particles $(8,17,23)$. 
Enzymes that confer Se resistance usually involve glutathione reductase (9).

It has previously been noted that small spheres of $\operatorname{Se}(0)$ form on the cell surface of a gram-positive rod, Bacillus selenitireducens strain MLS10, after respiratory growth on selenite (41). Here we examined this phenomenon more closely to document exogenous $\mathrm{Se}(0)$ nanosphere formation by three physiologically and phylogenetically diverse species of Se-respiring bacteria: the haloalkaliphile $B$. selenitireducens isolated from Mono Lake in California, the halophile Selenihalanaerobacter shriftii (strain DSSE1) isolated from the Dead Sea (42), and the freshwater organism Sulfurospirillum barnesii (strain SES3) isolated from a drainage slough in Nevada $(28,40)$. We also harvested the $\mathrm{Se}(0)$ spheres from cultures of these bacteria and removed the cellular debris. We examined the spectroscopic characteristics (UV-visible and Raman) of the purified preparations of biologically formed $\mathrm{Se}(0)$ and compared them to the spectroscopic characteristics of abiotically formed $\mathrm{Se}(0)$. From this we gained insight into the unique internal structural arrangements of the selenium atoms.

\section{MATERIALS AND METHODS}

Preparation of biogenic and chemical $\operatorname{Se}(0)$ for physical characterization. $S$. barnesii and $S$. shriftii were grown in anaerobic batch cultures with Se(VI) (10 to $20 \mathrm{mM}$ ) as the electron acceptor, while $B$. selenitireducens was grown with $10 \mathrm{mM}$ Se(IV) $(28,41,42)$. The compositions of the three media have been described previously and are not described in detail here; the media all contained lactate as the electron donor, and vitamins and yeast extract were added as growth supplements. However, the three media differed substantially in $\mathrm{pH}$, salinity, and buffering systems, as follows: for $S$. barnesii the $\mathrm{pH}$ of the medium was 7.3 , the salinity was $2 \mathrm{~g} /$ liter, and the buffer was phosphate plus bicarbonate- $\mathrm{CO}_{2}$; for $S$. shriftii the $\mathrm{pH}$ of the medium was 7.0, the salinity was $205 \mathrm{~g} / \mathrm{liter}$, and the buffer was piperazine- $N, N^{\prime}$-bis(2-ethanesulfonic acid) (PIPES); and for B. selenitireducens the $\mathrm{pH}$ of the medium was 9.8 , the salinity was $56 \mathrm{~g} / \mathrm{liter}$, and the buffer was carbonate-bicarbonate. For recovery of extracellular Se nanospheres, all three cultures were first grown with nitrate in lieu of Se oxyanions. Biogenic elemental selenium was formed by bacterial reduction of Se(IV) added to these cultures after harvesting and washing. Nitrate-grown cultures of B. selenitireducens strain MLS10, $S$. barnesii strain SES3, and $S$. shriftii strain DSSE1 were grown separately in $500 \mathrm{ml}$ of medium by using the methods described above. Late-exponential-phase cells were washed and resuspended in anaerobic minimal salts medium devoid of any chemical reductant (e.g., cysteine-HCl). $\mathrm{Na}_{2} \mathrm{SeO}_{3}(3.0$ $\mathrm{mM}$ ) and $2.0 \mathrm{mM}$ sodium lactate were added to each serum bottle containing 50 $\mathrm{ml}$ of a cell suspension. The bottles were placed in a $25^{\circ} \mathrm{C}$ shaking $(140 \mathrm{rpm})$ incubator for 3 days, and during this time the cells reduced $\mathrm{Se}(\mathrm{IV})$ to $\mathrm{Se}(0)$, as indicated by the appearance of a bright red precipitate. Cellular material was removed from the $\mathrm{Se}(0)$ particles by using a modified procedure of Laddaga and MacLeod (21). The cell suspensions containing Se(0) were ultrasonicated at 100 $\mathrm{W}$ for $2 \mathrm{~min}$ and centrifuged at $1,500 \times g$ for $30 \mathrm{~min}$. The pellets were resuspended, ultrasonicated, and centrifuged $(1,500 \times g)$ sequentially in $0.5 \mathrm{M} \mathrm{NaCl}$, $0.5 \mathrm{M}$ sucrose, and finally a complete salts solution composed of $17.5 \mathrm{~g}$ of $\mathrm{NaCl}$ per liter, $0.74 \mathrm{~g}$ of $\mathrm{KCl}$ per liter, $12.3 \mathrm{~g}$ of $\mathrm{MsSO}_{4} \cdot 7 \mathrm{H}_{2} \mathrm{O}$ per liter, and $0.15 \mathrm{~g}$ of Tris buffer per liter, and the $\mathrm{pH}$ was adjusted to 7.5. The cells were then lysed in $35 \mathrm{ml}$ of the complete salts solution containing $0.020 \mathrm{~g}$ of egg white lysozyme which was incubated at $22^{\circ} \mathrm{C}$ for $18 \mathrm{~h}$. The lysed cells were rinsed away from the $\mathrm{Se}(0)$ by resuspension, ultrasonication, incubation ( 3 to $4 \mathrm{~h}$ ), and sequential centrifugation $(8,000$ to $10,000 \times g)$ with the complete salts solution, $0.25 \mathrm{M}$ $\mathrm{NaOH}, 0.1 \mathrm{M} \mathrm{NaOH}, 10 \mathrm{mM} \mathrm{Na}{ }_{2} \mathrm{HPO}_{4}$ (adjusted to $\mathrm{pH} 7.3$ ), and carbon-free, distilled, deionized water. The cleaned $\mathrm{Se}(0)$ was then resuspended in distilled, deionized water.

Two forms of elemental selenium were synthesized chemically. Colloidal amorphous red elemental selenium $\left[\mathrm{Se}(0)_{\text {red }}\right]$ was prepared by oxidation of gaseous hydrogen selenide $\left[\mathrm{H}_{2} \mathrm{Se}_{(\mathrm{g})}\right]$ in water. Hydrogen selenide $(5,060 \mathrm{ppm})$ in $\mathrm{N}_{2}$ (Scientific Gas Products, Ashland Chemical Co., Columbus, Ohio) was sparged at a rate of $\sim 300 \mathrm{ml} \cdot \min ^{-1}$ into $800 \mathrm{ml}$ of $0.1 \mu \mathrm{M} \mathrm{NaOH}(\mathrm{pH} \sim 10)$ simultaneously with $\mathrm{O}_{2}$ at a flow rate equal to that of $\mathrm{H}_{2} \mathrm{Se}$. During the 6-h reaction the solution was vigorously stirred while colloidal, fine-grained, red $\mathrm{Se}(0)$ precipitated. After the $\mathrm{H}_{2} \mathrm{Se}$ source was removed, the solution was sparged with $\mathrm{O}_{2}$ for an additional 30 min to oxidize any remaining $\mathrm{HSe}^{-}$. The suspension was then bubbled with $\mathrm{N}_{2}$ for $1 \mathrm{~h}$ and pasteurized by heating it at $80^{\circ} \mathrm{C}$ for $1 \mathrm{~h}$. During these procedures the $\mathrm{Se}(0)$ remained red and was easily deflocculated by agitation.

Black vitreous elemental selenium $\left[\mathrm{Se}(0)_{\text {black }}\right]$ was formed by reduction of $\mathrm{Se}(\mathrm{IV})$ with ascorbic acid. Twenty-five milliliters of $5 \%(\mathrm{vol} / \mathrm{vol})$ ascorbic acid was added to $30 \mathrm{ml}$ of $167 \mathrm{mM} \mathrm{Na}_{2} \mathrm{SeO}_{3}$, which initiated rapid formation of a red $\mathrm{Se}(0)$ precipitate. The suspension was stirred for $1 \mathrm{~h}$ and then centrifuged at $11,000 \times g$ for $70 \mathrm{~min}$. After decanting, the $\mathrm{Se}(0)$ precipitate was rinsed with 50 $\mathrm{ml}$ of $50 \%(\mathrm{vol} / \mathrm{vol})$ ethanol-water and sonicated at $100 \mathrm{~W}$ for $3 \mathrm{~min}$ to disperse the precipitate. This procedure was repeated with $10 \mathrm{mM} \mathrm{Na} \mathrm{HPO}_{4}$ and distilled deionized water. The suspension was then bubbled with $\mathrm{N}_{2}$ for $1 \mathrm{~h}$ and pasteurized by heating it at $80^{\circ} \mathrm{C}$ for $1 \mathrm{~h}$. During these procedures the $\mathrm{Se}(0)$ gradually darkened from a red form to a dense gray-black form that exhibited vitreous morphology in scanning electron micrographs (data not shown).

Transmission electron microscopy (TEM) and scanning electron microscopy (SEM). Stained thin sections (used for micrographs) and unstained thin sections (used for collecting energy dispersive X-ray spectroscopy [EDS] spectra) of cell suspensions were prepared as described previously (12) by using Spurr lowviscosity resin (Marivac, St. Laurent, Quebec, Canada). Thin sections and untreated whole mounts of bacteria were placed on carbon-Formvar-coated 200mesh copper grids, and images were obtained with a Philips EM400T at $100 \mathrm{kV}$ under standard operating conditions with the liquid nitrogen anticontaminator in place. EDS was also performed at $100 \mathrm{kV}$ by using a spot size of $200 \mathrm{~nm}$, a current of $25 \mathrm{~mA}$, and a (live) counting time of $100 \mathrm{~s}$. For selected area electron diffraction we used the EM400T in the diffraction mode with a camera length of $575 \mathrm{~mm}$ and an exposure time of $20 \mathrm{~s}$. SEM images were obtained as described previously (36).

UV-visible and Raman spectroscopy. Samples of $\mathrm{Se}(0)$ particles suspended in water were placed in a quartz cell (path length, $1 \mathrm{~cm}$ ) and analyzed to obtain UV-visible absorption spectra with a Varian Cary 500 Scan UV-VIS-NIR spectrophotometer. Raman spectra were obtained with a Renishaw Ramascope Raman spectrometer equipped with an integral Leica DMLM microscope; 514.5-nm radiation was produced from a $20-\mathrm{mW}$ air-cooled $\mathrm{Ar}^{+}$laser (SpectraPhysics model 263C). The silicon Raman band at $520 \mathrm{~nm}$ was used to calibrate the spectrometer, and the spectral resolution was approximately $1.5 \mathrm{~cm}^{-1}$.

\section{RESULTS}

SEM and TEM of Se-respiring bacteria. Cells of selenitegrown $B$. selenitireducens produced abundant $\mathrm{Se}(0)$ nanospheres on the exterior of the cell envelope, as shown by the SEM image in Fig. 1A. TEM of thin sections also revealed the common presence of intracellular $\operatorname{Se}(0)$ granules when cells were grown on Se(IV) (Fig. 1B). When nitrate-grown washed cells were fed $\mathrm{Se}(\mathrm{IV})$, external $\mathrm{Se}(0)$ granules were the predominant form of $\mathrm{Se}(0)$ present, as shown by the wider-field image in Fig. 2A. The EDS spectra derived from a nanosphere indicated that it was composed entirely of selenium (Fig. 2B). The $\mathrm{Cu}$ peaks were associated with the TEM grid, the $\mathrm{Na}$ and $\mathrm{Cl}$ peaks reflected the high salt content of the medium, and the $\mathrm{C}$ and $\mathrm{O}$ peaks most likely were associated with cellular exudate. The lack of any other metal peaks in the spectrum indicated that the selenium occurred in the elemental state $[\mathrm{Se}(0)]$ rather than as a metal selenide $\left[\mathrm{Se}^{2-}\right]$. A higher magnification revealed the attachment of the external Se nanospheres on the cell surface (Fig. 2C). The smaller, dark, fine-grained precipitates on the cell surface were composed of Se as well, but they also produced EDS peaks for $\mathrm{Na}, \mathrm{Cl}, \mathrm{K}$, and $\mathrm{P}$ (data not shown), suggesting that they were mixed precipitates from the highly saline medium. The cell envelope and the external Se nanospheres also appeared to be encapsulated with an exopolymer. Selected area electron diffraction of nanospheres revealed a monoclinic crystal structure. Although patterns were difficult to generate (due to decay of the selenium nanospheres when they were exposed to the electron beam), we 


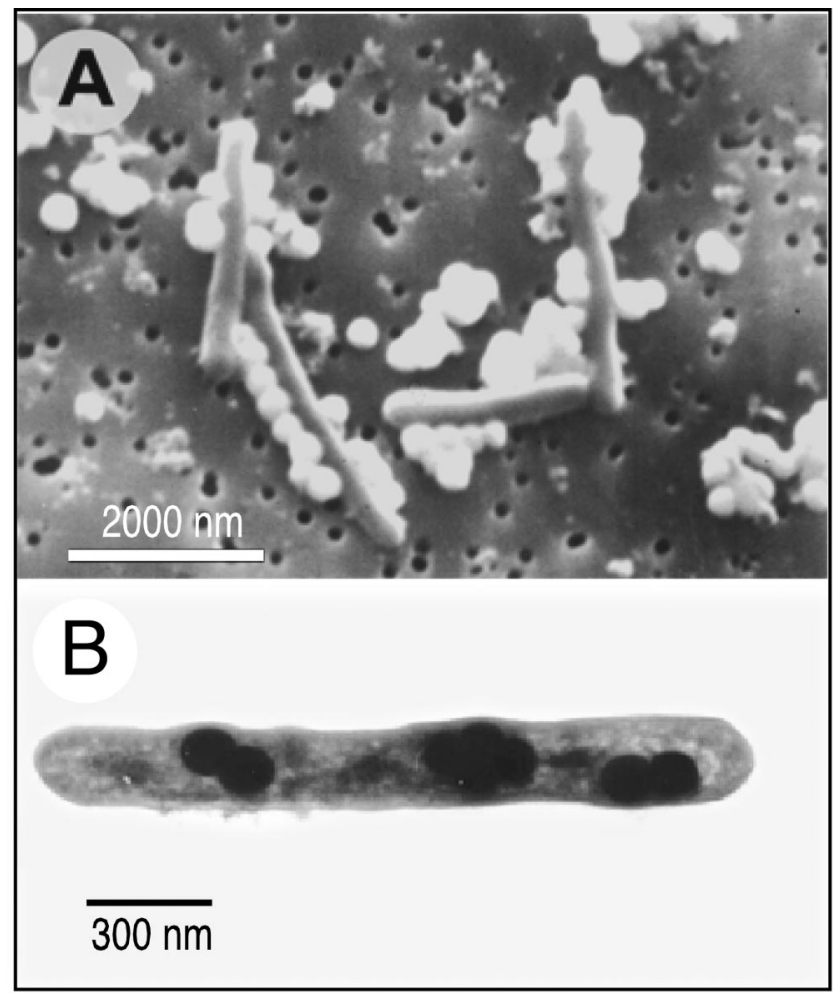

FIG. 1. Elemental selenium spheres formed by B. selenitireducens (A) SEM of cells growing on selenite and forming chains of $\mathrm{Se}(0)$ spheres. (B) TEM (thin section) of a cell grown on selenite that formed internalized $\mathrm{Se}(0)$.

measured d-spacings of $0.303,0.284,0.266,0.224,0.202$, and $0.185 \mathrm{~nm}$ (selected area electron diffraction transform data not shown). Owing to the small size of the nanospheres, this diffraction pattern is attributable to only the strongest reflections from the phases present.

We also observed similar external and internal accumulations of Se nanospheres in selenate-grown cells of the gramnegative species $S$. shriftii and $S$. barnesii. For Se(VI)-grown $S$. barnesii, TEM images typically showed that there were extensive accumulations of Se granules on the exterior of the cells, which apparently sloughed off the cell surfaces and formed even larger aggregates composed of many individual granules (Fig. 3A and B). The presence of internal Se nanospheres in this organism was also confirmed by examining thin sections, which documented the presence of nanospheres after growth with $\mathrm{Se}$ (VI) (Fig. 3C) and with nitrate-grown washed cells that were fed Se(IV) (Fig. 3D). S. shriftii produced both internal and external Se nanospheres when it was grown on nitrate, washed, and subsequently fed Se(VI) (Fig. 4A) or Se(IV) (Fig. 4B).

SEM images of purified Se nanospheres. The external Se(0) particles from all three cultures, after harvesting and cleansing, consisted of nanospheres that ranged in diameter from 200 to $400 \mathrm{~nm}$, and the most common diameter was $\sim 300 \mathrm{~nm}$, as observed in SEM images (Fig. 5A to $\mathrm{C}$ ). The $\mathrm{Se}(0)$ nanospheres were stable, as these structures persisted at least for several months when they were kept as solid suspensions in distilled water. In contrast, $\mathrm{Se}(0)$ chemically formed by auto-
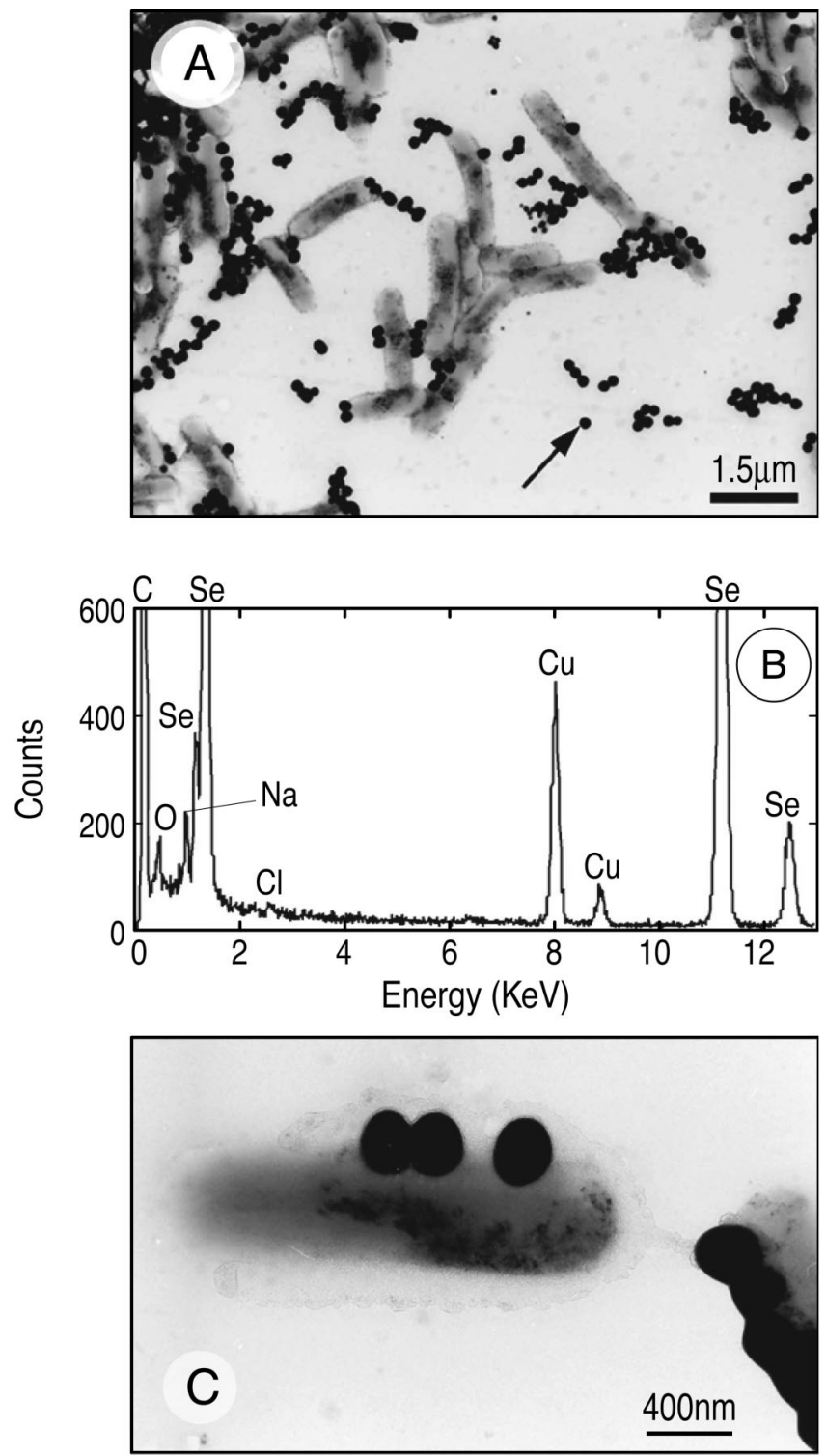

FIG. 2. (A) TEM (whole mount) of nitrate-grown washed cells of $B$. selenitreducens that were fed selenite, showing a large number of external $\mathrm{Se}(0)$ spheres. (B) EDS of the particle in panel A indicated by an arrow. (C) Higher-magnification TEM (whole mount) of nitrategrown cells.

oxidation of $\mathrm{H}_{2} \mathrm{Se}$ gas with $\mathrm{O}_{2}$ produced only unstructured, amorphous aggregates that ranged in diameter from 200 to 800 $\mathrm{nm}$ (Fig. 5D). Elemental Se formed by chemical reduction of $\mathrm{Se}$ (IV) with ascorbate produced a vitreous, black allotrope consisting of unstructured aggregates having various dimensions. The particle size distribution for this allotrope was extremely variable, and the range was particles as small as $10 \mathrm{~nm}$ (Fig. 5E) to aggregations as large as $50 \mu \mathrm{m}$ (Fig. 5F) because of the sticky nature of this material.

Spectral properties and Se atom arrangements of the purified Se nanospheres. The typical structural arrangements of $\mathrm{Se}$ atoms in the various allotropes of elemental selenium are rings or chains of Se atoms, which can have different molecular 


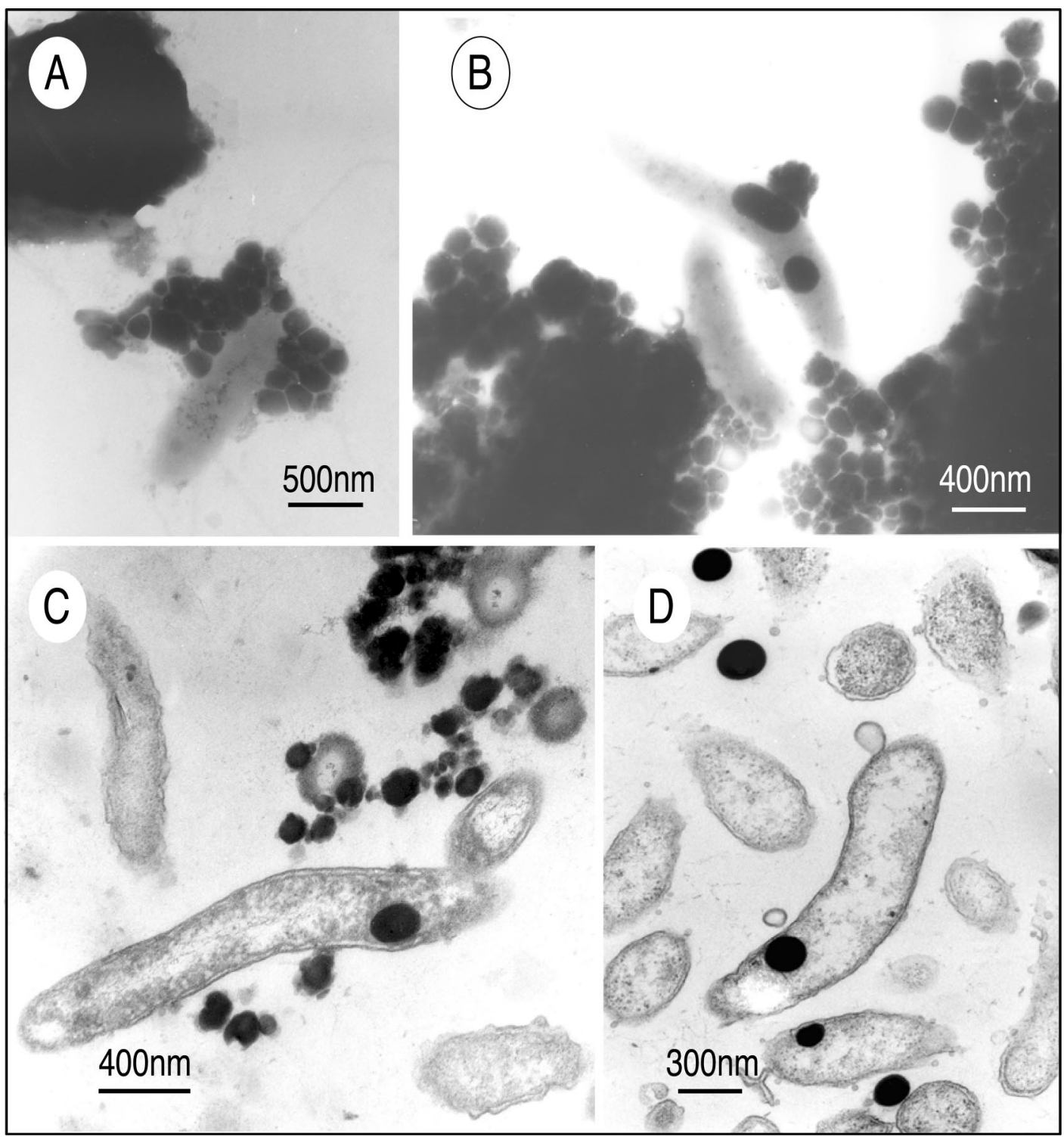

FIG. 3. TEM of S. barnesii, showing external and internal accumulations of Se granules. (A) Whole mount of cells grown on selenate, showing $\sim 30$ external granules attached to a cell. (B) Whole mount of two cells close to very large external aggregations of Se granules. EDS spectra indicated that all the dark granules in panels A and B are elemental selenium, similar to the spectrum shown in Fig. 2 (data not shown). (C) Thin section of selenate-grown cells, showing external and internal Se granules. (D) Thin section of cells grown on nitrate, washed, and given selenite, showing internal and external Se granules.

compositions or chain lengths, ranging from $\mathrm{Se}_{3}$ to $\mathrm{Se}_{12}(18)$. Figure 6 shows the UV-visible absorption spectra for the three Se samples obtained from $S$. barnesii, B. selenitireducens, and $S$. shriftii. These spectra are compared with the spectra of chemically formed $\mathrm{Se}(0)$ (Fig. 6, inset), which include the red, amorphous $\operatorname{Se}(0)$ form and the black, vitreous $\operatorname{Se}(0)$ form. The spectral properties of the samples obtained from the bacteria were considerably different than the spectral properties of the chemically formed $\mathrm{Se}(0)$. Indeed, rather than being uniform, the spectra obtained for the three biologically derived samples varied considerably from species to species, and the Se nanosphere samples from $S$. shriftii exhibited the most unusual and broadest absorption spectrum at wavelengths greater than 600 nm.
All the biological Se samples exhibited low bandgap features. We defined bandgap as the minimum energy needed to promote a valence electron into a conducting electron. The bandgap calculated for the red, amorphous $\mathrm{Se}(0)$ form was 2.1 $\mathrm{eV}$, which was considerably higher than the bandgaps for Se nanospheres derived from $S$. barnesii $(1.62 \mathrm{eV})$, S. shriftii (1.52 $\mathrm{eV})$, and B. selenitirducens $(1.67 \mathrm{eV})$. The bandgap variation seen in the biological samples was due to the different molecular configurations of the internal crystalline structure. The structural confinement of Se atoms within the 200- to $400-\mathrm{nm}$ spheres caused the decrease in the bandgap and resulted from increased $\pi-\pi$ and $\pi$-d transitions. This phenomenon is akin to that which has been observed elsewhere from clustering effects when increased Se ring-ring interactions caused a red shift 


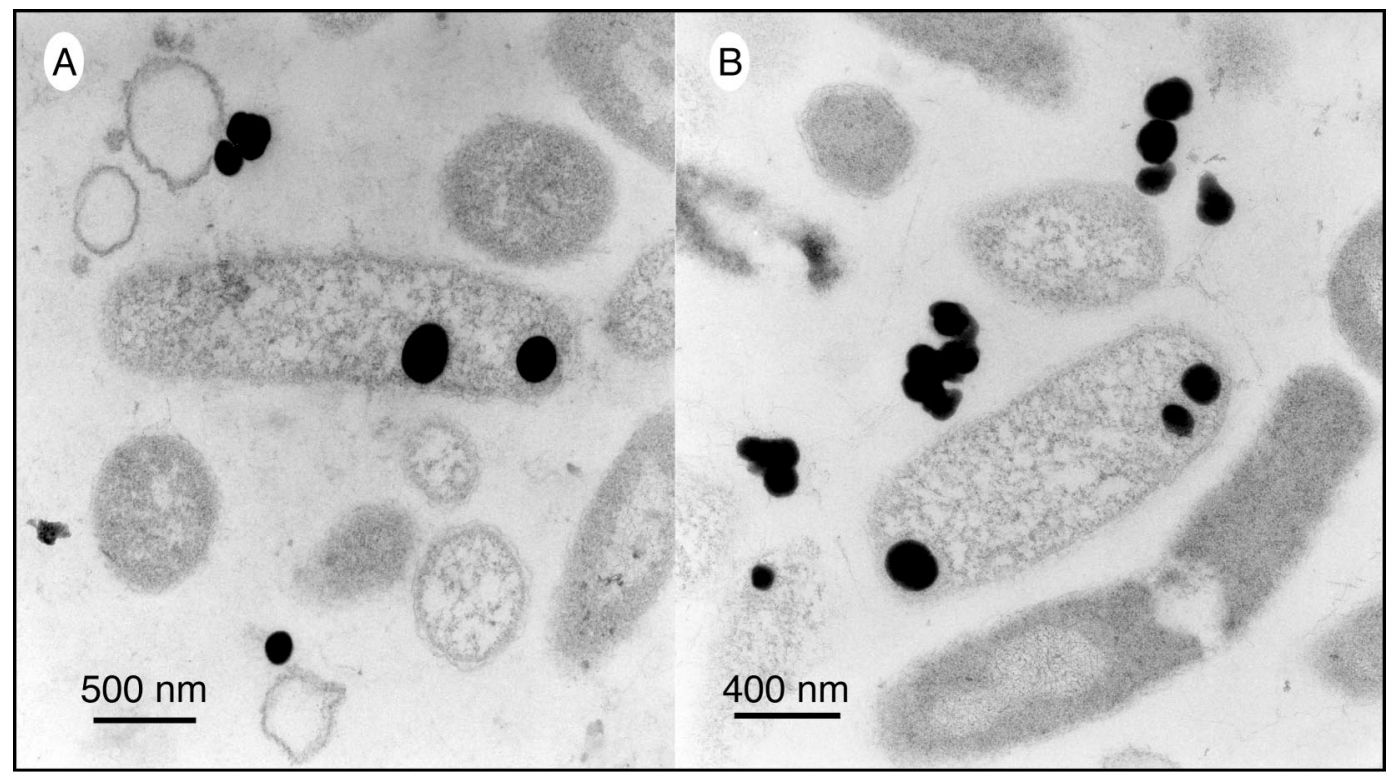

FIG. 4. TEM (thin sections) of S. shriftii grown on nitrate, washed, and resuspended with selenate (A) and selenite (B). The dark spheres are composed of elemental selenium, as determined from EDS spectra (data not shown).

(lower energy) in the absorption spectrum (22). This was apparent in the spectral differences among the three biological samples when they were compared to the chemically formed red, amorphous $\mathrm{Se}(0)$ (Fig. 6). By contrast, the black, vitreous $\mathrm{Se}(0)$ showed the typical broad, featureless absorption expected for large, amorphous, synthetically formed selenium clusters. The $S$. shriftii sample had another distinguishing feature. There were two optical absorption peaks at 780 and 820 $\mathrm{nm}$, indicating that there was a bimodal distribution. This revealed the presence of another Se molecular species within this bacterium's Se nanospheres (see below).

The three microbial samples also exhibited Raman spectra having distinctly different features (Fig. 7). Two of the samples ( $S$. barnesii and B. selenitireducens) had similar dominant $\mathrm{Se}_{6}$ units within their Se particles, while the third sample $(S$. shriftii) had a dominant $\mathrm{Se}_{8}$ unit of the $\mathrm{D}_{4 \mathrm{~d}}$ space group. The data also showed that poly(Se) was formed; the peak at 260 $\mathrm{cm}^{-1}$ was indicative of single-chain Se, while the peak at 234 $\mathrm{cm}^{-1}$ was a feature of Se polymer formation in addition to ring structures. The polymer is formed by close interactions between the $\mathrm{Se}_{8}$ rings via van der Waals bonds (5). $\mathrm{Se}_{6}$ vibrates when it is in the presence of a composite structure at 288 and $301 \mathrm{~cm}^{-1}$, which are the causes of the bimodal distribution which we observed in the absorption spectra. The $S$. barnesii samples had a slightly different vibrational spectrum than the $B$. selenitireducens samples, which also had a $\mathrm{Se}_{6}$ structure, but they differed in the configuration of the $\mathrm{Se}_{6}$ chains. In $B$. selenitireducens, $\mathrm{Se}_{6}$ vibrational modes $\mathrm{A} 1 \mathrm{~g}$ and $\mathrm{Eg}$ were observed at 244 and $225 \mathrm{~cm}^{-1}$, respectively. These modes were dominated by the more stable $\mathrm{D}_{3 \mathrm{~d}}$ (chair) structure. While $S$. barnesii also forms $\mathrm{Se}_{6}$, in this case it produced the spectrum typical of $\mathrm{Se}_{6}$ with the more unstable $\mathrm{C}_{2 \mathrm{v}}$ (boat) structure; these modes were observed at 228 and $241 \mathrm{~cm}^{-1}$, findings which compare favorably with previously described findings.
However, these vibrations can also be strongly linked to Se polymer structures, as previously described $(4,31)$.

\section{DISCUSSION}

In this study we documented the occurrence of both intracellular and extracellular Se granules in three phylogenetically and physiologically distinct bacteria that are able to respire Se oxyanions. Thus, this phenomenon appears to be widespread among such bacteria. Indeed, it is not just confined to the bacteria that are capable of dissimilatory reduction of Se oxyanions, as it has also been reported in Se-resistant bacteria. For example, electron micrographs of Wollinella succinogenes (43), Enterobacter cloacae (23), and Stenotrophomonas maltophilia (8) have all shown that spherical granules of $\mathrm{Se}(0)$ that were similar sizes were formed after cells were exposed to Se(IV) or $\mathrm{Se}(\mathrm{VI})$. Intracellular $\mathrm{Se}(0)$ granules have also been reported in cells of the photosynthetic bacterium Chromatium vinosum, although in this case the granules were generated by the lightinduced oxidation of $\mathrm{H}_{2} \mathrm{Se}$ rather than by the reduction of $\mathrm{Se}$ oxyanions (25).

It is noteworthy that the formation of Se nanospheres is not confined to biological systems since Se particles that are similar sizes can be generated by chemical synthesis. Thus, monoclinic $\mathrm{Se}(0)$ nanospheres were formed by chemical reduction of selenite with cytochrome $c_{3}(1)$. Nanospheres composed of amorphous $\mathrm{Se}(0)$ appeared as temporary intermediates in the synthesis of trigonal $\mathrm{Se}(0)$ used to form Se nanowires $(10,11)$. These Se allotropes were produced under harsher conditions in which hydrazine was used for reduction of $\mathrm{Se}(\mathrm{IV})$ at $\sim 100^{\circ} \mathrm{C}$. We did not observe $\mathrm{Se}(0)$ nanosphere formation when we used milder ascorbate reduction of Se(IV) at room temperature, a reaction that resulted instead in the formation of the black, vitreous $\mathrm{Se}(0)$ allotrope. However, neither of 

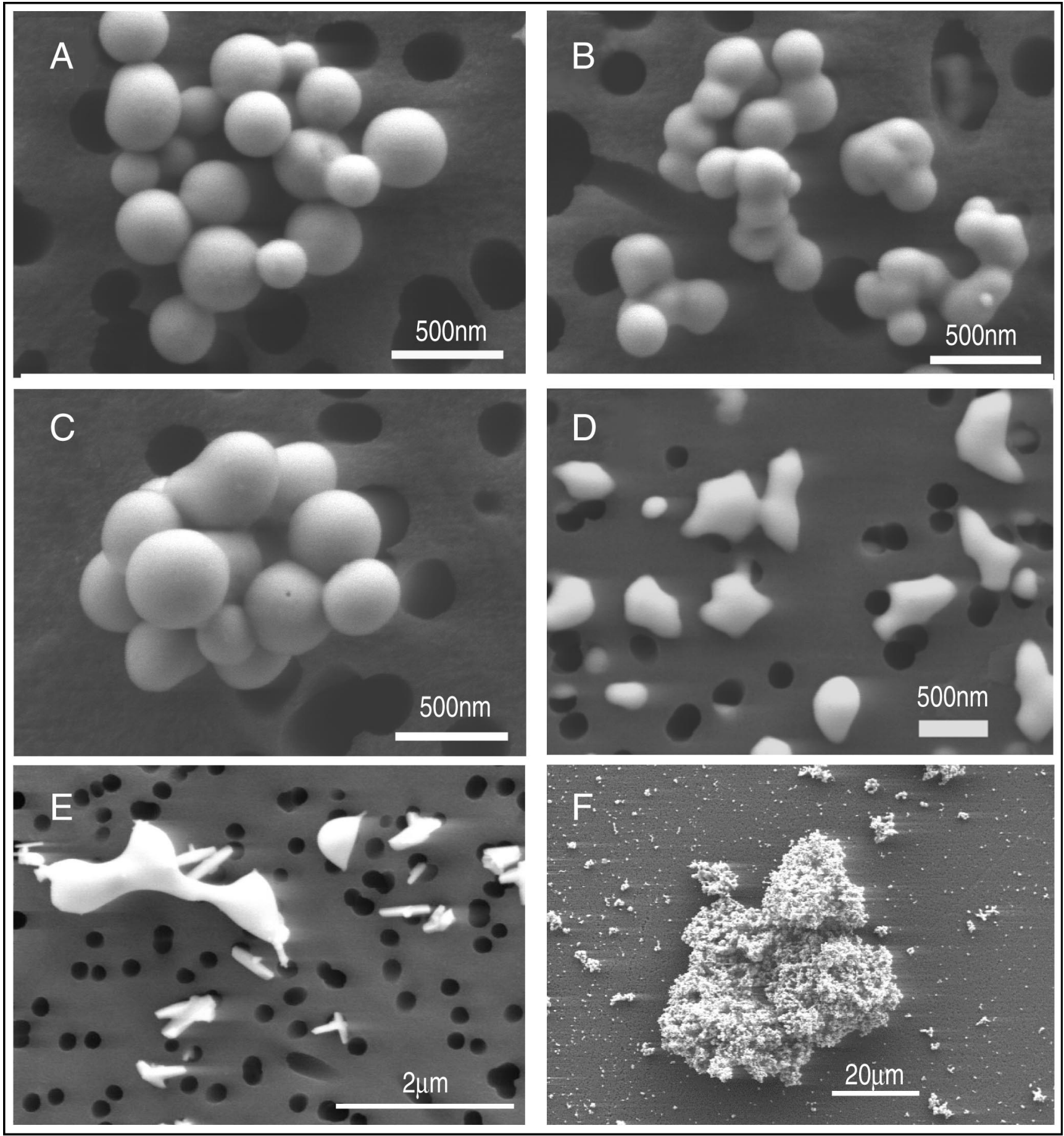

FIG. 5. SEM of cleansed elemental selenium formed by bacteria (A to C) or synthesized chemically (D to F). (A to C) Selenium spheres formed by B. selenitireducens MLS10 (A), S. barnesii SES3 (B), and S. shriftii DSSE1 (C). (D) Elemental selenium formed by oxidation of $\mathrm{H}_{2} \mathrm{Se}$ with $\mathrm{O}_{2}$ in alkaline ( $\mathrm{pH}$ 10.0) water. (E and F) High- and low-magnification images, respectively, of vitreous black elemental selenium formed by reduction of selenite with ascorbate.

these previously described artificial chemical synthesis studies presented data on the spectral properties of the Se nanospheres themselves that would allow us to infer the internal arrangement(s) of their Se atoms. This can also be said to be the case for all of the studies that documented formation of $\mathrm{Se}(0)$ granules by the Se-resistant bacteria mentioned above; the authors made no further attempts to purify these materials or to examine their inherent spectral properties. 


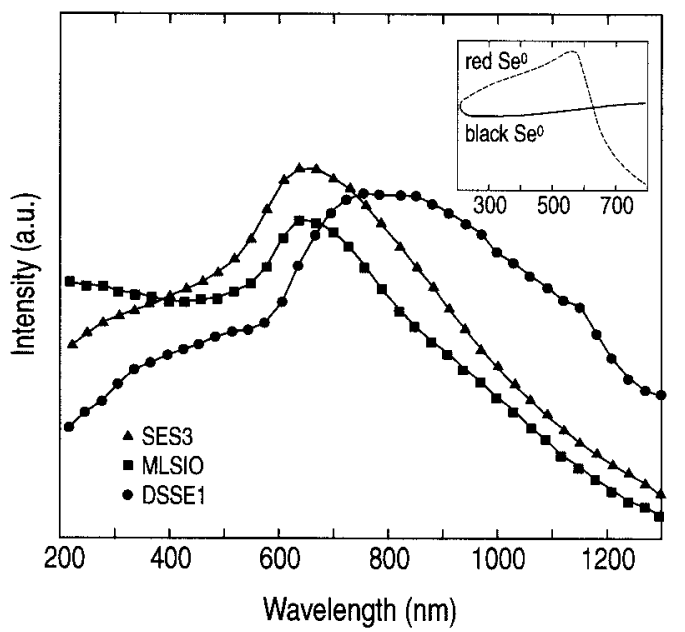

FIG. 6. UV-visible spectra of purified Se nanospheres from S. barnesii SES3, B. selenitireduncens MLS10, and $S$. shriftii DSSE1. (Inset) Comparative spectra of chemically produced red, amorphous $\mathrm{Se}(0)$ and black, vitreous $\operatorname{Se}(0)$. a.u., arbitrary units.

Elemental selenium is known to form three specific types of structural subsets, a six-member ring, an eight-member ring, and infinite $\alpha$-helical chains with a Se-Se distance of approximately $2.37 \AA$ and a bond angle of $103^{\circ}(44)$. Thus, we propose that the nanospheres are composed of interconnected threedimensional nets of selenium in which both chain and ring structural aspects are maintained, factors that should result in the spherical shape. Similar types of two-dimensional and three-dimensional Se nets have been observed for alkali metalboron-selenium compounds (13) and have been proposed for partially disordered phases of Se (20). Finally, it has even been proposed that $\mathrm{Se}$ chains with terminal $\mathrm{Cl}$ atoms are able to interact with other Se chains to form such Se-based threedimensional networks (19), which might account in part for the presence of $\mathrm{Cl}$ in Fig. 2B.

In our investigations we noted that extracellular $\mathrm{Se}(0)$ accumulation was far more common than intracellular $\operatorname{Se}(0)$ accumulation (Fig. 1 and 3) and that this was even more pro-

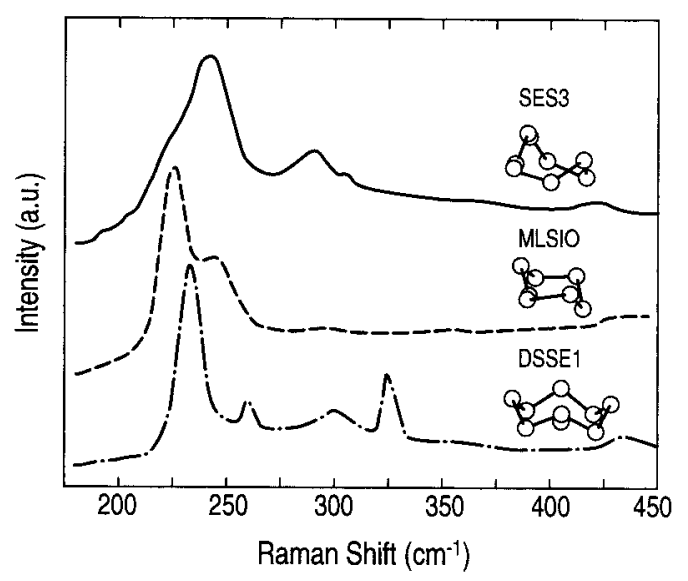

FIG. 7. Raman spectra at $514.5 \mathrm{~nm}$ of purified Se nanospheres from $S$. barnesii SES3, B. selenitireducens MLS10, and S. shriftii DSSE1. a.u., arbitrary units. nounced when nitrate-grown cells were washed and then fed $\mathrm{Se}$ (IV) (Fig. 2). It does not seem possible that the large external accumulations of $\mathrm{Se}(0)$ granules on the exterior cell surfaces of all of the microorganisms studied could have been derived from primary cytoplasmic synthesis and subsequent export. Such a system for respiratory reduction of $\mathrm{Se}(\mathrm{VI})$ to $\mathrm{Se}(0)$ would be, at the least, extremely discomforting for individual cells, and because of the size of the internal Se particles, the particles should be released only upon cell lysis. Relatively little is known about dissimilatory selenate reductases of prokaryotes, but like other respiratory enzymes, they are usually associated with the peripheral cell envelope. Only the respiratory selenate reductase of Thauera selenatis has been characterized, and it is located in the periplasm (35), which supports the idea that the bulk of the $\mathrm{Se}(\mathrm{VI})$ and $\mathrm{Se}(\mathrm{IV})$ reduction to $\operatorname{Se}(0)$ occurs on or outside the envelope. To date, no work has been done on dissimilatory selenite reductases.

We can make a simple calculation to determine what fraction of the total dissolved Se oxyanion pool is converted to exterior deposits of $\mathrm{Se}(0)$ associated with the cell surface, as shown by a cell of $S$. barnesii in Fig. 3A, on which we counted 30 externally attached $\mathrm{Se}(0)$ granules. If it is assumed that each granule is sphere with a $300-\mathrm{nm}$ diameter, then each nanosphere has a volume of $\sim 1.4 \times 10^{-20} \mathrm{~m}^{3}$. The specific gravity of $\operatorname{Se}(0)$ is $4.5 \mathrm{~g} \mathrm{ml}^{-1}$ (or $4.5 \mathrm{~g} / 10^{-6} \mathrm{~m}^{3}$ ), and therefore $1.0 \times$ $10^{-20} \mathrm{~m}^{3}$ contains $4.5 \times 10^{-5} \mathrm{ng}$ of Se, or there is $6.3 \times 10^{-5}$ ng of Se per nanosphere or $8.7 \times 10^{-7}$ nmol of Se per nanosphere. If it is assumed that the cell density at the end of exponential growth was $\sim 10^{11}$ cells/liter (26) and that each bacterium had $30 \mathrm{Se}(0)$ spheres on its surface (as shown in Fig. $3 \mathrm{~A})$, this Se would represent $\sim 2.4 \mathrm{mmol}$ of $\mathrm{Se}(0)$ or about one-quarter of the available $10 \mathrm{mM} \mathrm{Se}(\mathrm{VI})$ initially present in the medium. The common occurrence of even larger $\operatorname{Se}(0)$ aggregates in the TEM fields (Fig. 2A) suggests that the amount of reduced Se was vastly larger than this estimate. Because the Se nanospheres eventually slough off the individual cells, the $\mathrm{Se}(0)$ particles represent the ultimate repository for all of the $\mathrm{Se}(\mathrm{VI})$ added at the start of incubation. This also suggests that the external and internal $\mathrm{Se}(0)$ nanospheres arise independent of each other and by different mechanisms. The external nanosphere accumulation is probably directly tied to the respiratory Se reductases.

What then could be the function of the internal, well-structured accumulations of selenium? It is possible that they are receptacles for storage of internally reduced $\mathrm{Se}(\mathrm{VI})$ or $\mathrm{Se}(\mathrm{IV})$ ions that have bypassed the membrane-associated respiratory reductases of the cell envelope and have entered the cell via sulfate or perhaps nitrite transporters. Considering the fact the organisms were grown in the presence of high concentrations $(\sim 10 \mathrm{mM})$ of Se oxyanions, it is quite likely that some of these toxicants made it past the outer respiratory membrane barrier. Thus, the cells would need to perform a detoxification reaction with excess internal Se oxyanions by reducing them to $\mathrm{Se}(0)$ and storing them in segregated areas within the cells. It is not clear from the TEM images, however, that the internal Se nanospheres were surrounded by a distinct internal membrane. In the case of $B$. selenitireducens, storage in this manner could have a selective advantage by forming a reservoir of $\mathrm{Se}(0)$ when external electron acceptors are scarce because this organism can perform dissimilatory reduction of $\mathrm{Se}(0)$ to $\mathrm{H}_{2} \mathrm{Se}(15)$. 
In summary, we studied elemental selenium aggregations produced by the metabolic activities of three different species of anaerobic bacteria that respire or breathe oxyanions of selenium. The complexity of the nanosphere UV-visible (Fig. 6) and Raman spectra (Fig. 7) showed that more than a single Se molecular chain structure was present, and indeed at times several structures were observed. In turn, the biologically formed Se nanospheres had very different spectral properties than chemically formed $\mathrm{Se}(0)$ (Fig. 6).

Production of coordinated nanoclusters with a specific molecular orientation has been well-studied by synthetic chemists. In this case, however, nature has provided an intriguing situation, in which different bacterial species produce selenium nanoclusters that have different structural orientations and optical properties. What can account for this variation? We believe that the differences are likely caused by a corresponding diversity of enzymatic reactions (with different electrochemical potentials) that concurrently take place on the outer membranes of the various bacteria. Thus, various constitutive enzymes (e.g., selenate, selenite, nitrate, nitrite, and trimethylamine oxide reductases) may be present to different extents in the cell envelopes of the different organisms, and they can likely shift their electrons to $\operatorname{Se}(\mathrm{IV})$, thereby reducing this form to $\operatorname{Se}(0)(6,29,33)$. It remains to be determined if the diverse properties of the biologically based Se nanospheres can be reliably reproduced biosynthetically and, if they can be, whether they have a practical application in the field of nanotechnology.

Our findings illustrate the relevance of screening the natural world for novel biological nanostructures that have unique physical properties that cannot currently be produced by purely chemical means. Although the formation of $\operatorname{Se}(0)$ by microorganisms has been known for some time, the physical properties of the aggregates have not been examined previously. In this work we found unique signatures associated with the spectra from anaerobes isolated from freshwater, hypersaline, and alkaline saline habitats. Since the microbial diversity of Se-respiring prokaryotes is much broader than these three representative species and includes hyperthermophiles capable of respiring Se oxyanions at $\sim 90^{\circ} \mathrm{C}(16,30,39)$, a survey of unexamined cultures for Se nanosphere formation and the associated optical properties of the nanospheres is warranted. Furthermore, if $\mathrm{Se}(0)$ nanospheres with characteristic biological optical spectra are found in suboxic Se-contaminated sediments, then the data could be taken as strong evidence that the nanospheres had a microbiological origin rather than a chemical origin (24). Since the concentration of selenium oxyanions even in contaminated water is usually low (e.g., $<1 \mu \mathrm{M}$ ), it would be best to first attempt this in evaporation ponds where the brines have high levels of selenium oxyanions $(\sim 40$ $\mu \mathrm{M})$ and the underlying sediments have marked selenate reductase activity $(26,27)$. On a much more speculative level, such a characteristic biosignature imposed on a trace element like selenium may conceivably be useful in the search for evidence of extinct microbial communities in sedimentary deposits of extraterrestrial origin (i.e., Mars).

\section{ACKNOWLEDGMENTS}

We thank M. J. Oremland, H. L. Ehrlich, L. G. Miller, L. Young, S. Fendorf, and J. F. Stolz for their constructive comments and D. Moyles for expert assistance with the TEM.
R.S.O. was funded by the USGS National Research Program and a NASA Exobiology grant, and T.J.B. was supported by Natural Science and Engineering Research Council of Canada (NSERC) and USDOE-NABIR grants. The TEM was performed at the NSERC Guelph Regional STEM Facility at the University of Guelph, whose maintenance is partially funded by an NSERC Major Facilities Access grant to T.J.B. P.A. and S.C. were supported by the NSF-funded Nanoscale Science and Engineering Center at Rensselaer Polytechnic Institute.

\section{REFERENCES}

1. Abdelouas, A., W. L. Gong, W. Lutze, J. A. Shelnutt, R. Franco, and I. Moura. 2000. Using cytochrome $c_{3}$ to make selenium nanowires. Chem. Mater. 12:1510-1512.

2. Boyington, J. C., V. N. Gladyshev, S. V. Khangulov, T. C. Stadtman, and P. D. Sun. 1997. Crystal structure of formate dehydrogenase H: catalysis involving Mo, molybdopterin, selenocysteine, and an $\mathrm{Fe}_{4} \mathrm{~S}_{4}$ cluster. Science 275:1305-1308.

3. Brandt, W., and M. Oremland. 1976. Positron measurements of selenium recrystallization rates. Phys. Lett. 57A:387-389.

4. Brassington, N. J., H. G. M. Edwards, and V. Fawcett. 1987. 1987. The vibrational Raman spectra of selenium trioxide ag. Spectrochem. Acta 43A: 451-454.

5. Carini, G., M. Cutroni, G. Galli, P. Migliardo, and F. Wanderlingh. 1980. Raman scattering in $a$-Se bulk near $T_{0}$. Solid State Commun. 33:1139-1141.

6. DeMoll-Decker, H., and J. M. Macy. 1993. The periplasmic nitrite reductase of Thauera selenatis may catalyze the reduction of selenite to elemental selenium. Arch. Microbiol. 160:241-247.

7. Dowdle, P. R., and R. S. Oremland. 1998. Microbial oxidation of elemental selenium in soil slurries and bacterial cultures. Environ. Sci. Technol. 32: 3749-3755.

8. Dungan, R. S., S. R. Yates, and W. T. Frankenberger, Jr. 2003. Transformations of selenate and selenite by Stenotrophomonas maltophilia isolated from a seleniferous agricultural drainage pond sediment. Environ. Microbiol. 5:287-295

9. Ganther, H. 1968. Selenotrisulfides. Formation by the reaction of thiols with selenous acid. Biochemistry 7:2898-2905.

10. Gates, B., B. Mayers, B. Cattle, and Y. Xia. 2002. Synthesis and characterization of uniform nanowires of trigonal selenium. Adv. Funct. Mater. 12: 219-227.

11. Gates, B., B. Mayers, B. Grossman, and Y. Xia. 2002. A sonochemical approach to the synthesis of crystalline selenium nanowires in solutions and on solid supports. Adv. Mater. 14:1749-1752.

12. Glasauer, S., P. G. Weidler, S. Langley, and T. J. Beveridge. 2003. Controls on Fe reduction and mineral formation by a subsurface bacterium. Geochim. Cosmochim. Acta 67:1277-1288.

13. Hammerschmidt, A., A. Lindemann, M. Doch, C. Koster, C., and B. Krebs. 2002. 2D-polymeric anion networks: the two novel perselenoborates $\mathrm{BaB}_{2} \mathrm{Se}_{6}$ and $\mathrm{Ba}_{2} \mathrm{~B}_{4} \mathrm{Se}_{13}$. Z. Anorg. Alleg. Chem. 628:1561-1567.

14. Heider, J., and A. Bock. 1993. Selenium metabolism in micro-organisms. Adv. Microb. Physiol. 35:71-109.

15. Herbel, M. J., J. Switzer Blum, S. E. Borglin, and R. S. Oremland. 2003. Reduction of elemental selenium to selenide: experiments with anoxic sediments and bacteria that respire Se-oxyanions. Geomicrobiol. J. 20:587-602.

16. Huber, R., M. Sacher, A. Vollman, H. Huber, and D. Rose. 2000. Respiration of arsenate and selenate by hyperthermophilic archaea. Syst. Appl. Microbiol. 23:305-314.

17. Kessi, J., M. Ramuz, E. Wejrli, M. Spycher, and R. Bachofen. 1999. Reduction of selenite and detoxification of elemental selenium by the phototrophic bacterium Rhodospirillum rubrum. Appl. Environ. Microbiol. 65:47344740 .

18. Kohara, S., S. Goldbach, N. Koura, M.-L. Sabsoungi, and L. A. Curtiss. 1998. Vibrational frequencies of small selenium molecules. Chem. Phys. Lett. 287:282-288.

19. Kondakova, O. A., A. S. Zyubin, S. A. Dembovsky, and N. S. Kurnakov. 2001 Quantum-chemical modeling of chlorine-doped and hypervalent defects participation in reconstruction of the a-Se structure. J. Optoelectr. Adv. Mater. 3:847-853

20. Koslowski, T., M. Koblischke, and A. Blumen. 2002. Modified small-world networks as models of liquid and amorphous selenium. Phys. Rev. B 66: 064205-1-064205-7.

21. Laddaga, R. A., and R. A. MacLeod. 1982. Effects of wash treatments on the ultrastructure and lysozyme penetrability of the outer membrane of various marine and two terrestrial gram-negative bacteria. Can. J. Microbiol. 28: 318-324.

22. Lin, Z., Z. Wang, W. Chen, L. Lin, G. Li, Z. Liu, H. Han, and Z. Wang. 1996. Absorption and Raman spectra of $\mathrm{Se}_{8}$-ring clusters in zeolite 5A. Solid State Commun. 100:841-843.

23. Losi, M. E., and W. T. Frankenberger, Jr. 1997. Reduction of selenium oxyanions by Enterobacter cloacae SLD1a-1: isolation and growth of the bacterium and its expulsion of selenium particles. Appl. Environ. Microbiol. 63:3079-3084. 
24. Myneni, S. C. B., T. K. Tokunaga, and G. E. Brown, Jr. 1997. Abiotic selenium redox transformations in the presence of $\mathrm{Fe}(\mathrm{II}, \mathrm{III})$ oxides. Science 278:1106-1109.

25. Nelson, D. C., W. H. Casey, J. D. Sison, E. R. Mack, A. Ahmad, and J. S. Pollack. 1996. Selenium uptake by sulfur-accumulating bacteria. Geochim. Cosmochim. Acta 60:3531-3539.

26. Oremland, R. S., J. T. Hollibaugh, A. S. Maest, T. S. Presser, L. Miller, and C. Culbertson. 1989. Selenate reduction to elemental selenium by anaerobic bacteria in sediments and culture: biogeochemical significance of a novel, sulfate-independent respiration. Appl. Environ. Microbiol. 55:2333-2343.

27. Oremland, R. S., N. A. Steinberg, N. A., A. S. Maest, L. G. Miller, and J. T. Hollibaugh. 1990. Measurement of in situ rates of selenate removal by dissimilatory bacterial reduction in sediments. Environ. Sci. Technol. 24: 1157-1164.

28. Oremland, R. S., J. Switzer Blum, C. W. Culbertson, P. T. Visscher, L. G Miller, P. Dowdle, and F. E. Strohmaier. 1994. Isolation, growth, and metabolism of an obligately anaerobic, selenate-respiring bacterium, strain SES-3. Appl. Environ. Microbiol. 60:3011-3019.

29. Oremland, R. S., J. S. Blum, A. Burns Bindi, P. R. Dowdle, M. Herbel, and J. F. Stolz. 1999. Simultaneous reduction of nitrate and selenate by cell suspensions of selenium-respiring bacteria. Appl. Environ. Microbiol. 65: 4385-4392.

30. Oremland, R. S., and J. F. Stolz. 2000. Dissimilatory reduction of selenate and arsenate in nature, p. 199-224. In D. R. Lovley (ed.), Environmental metal-microbe interaction. ASM Press, Washington, D.C.

31. Poborchin, V. V., A. V. Kolobov, H. Oyanagi, S. G. Romanov, and K. Tomaka. 1997. Structure of selenium incorporated into nanochannels of mordenite: dependence on ion exchange and method of incorporation. Chem. Phys. Lett. 280:10-16.

32. Presser, T. S. 1998. The Kesterson effect. Environ. Manag. 18:437-454.

33. Rech, S. A., and J. M. Macy. 1992. The terminal reductases for selenate and nitrate respiration in Thauera selenatis are two distinct enzymes. J. Bacteriol. 174:7316-7320.
34. Shisler, J. L., T. G. Senkevich, M. J. Berry, and B. Moss. 1998. Ultravioletinduced cell death blocked by a selenoprotein from a human dermatotrophic poxvirus. Science 279:102-105

35. Shröder, I., S. Rech, T. Krafft, and J. M. Macy. 1997. Purification and characterization of the selenate reductase from Thauera selenatis. J. Biol. Chem. 272:23765-23768.

36. Smith, R. L., F. S. Strohmaier, F. S., and R. S. Oremland. 1985. Isolation of anaerobic oxalate degrading bacteria from freshwater lake sediments. Arch. Microbiol. 14:8-13.

37. Stadtman, T. C. 1996. Selenocysteine. Annu. Rev. Biochem. 65:83-100.

38. Steinberg, N. A., and R. S. Oremland. 1990. Dissimilatory selenate reduction potentials in a diversity of sediment types. Appl. Environ. Microbiol. 56: 3550-3557.

39. Stolz, J. F., and R. S. Oremland. 1999. Bacterial respiration of selenium and arsenic. FEMS Microbiol. Rev. 23:615-627.

40. Stolz, J. F., D. J. Ellis, J. Switzer Blum, D. Ahmann, R. S. Oremland, and D. R. Lovley. 1999. Sulfurospirillum barnesii sp. nov., Sulfurospirillum arsenophilus sp. nov., and the Sulfurospirillum clade in the epsilon proteobacteria. Int. J. Syst. Bacteriol. 49:1177-1180.

41. Switzer Blum, J., A. Burns Bindi, J. Buzzelli, J. F. Stolz, and R. S. Oremland. 1998. Bacillus arsenicoselenatis sp. nov. and Bacillus selenitireducens sp. nov.: two haloalkaliphiles from Mono Lake, California that respire oxyanions of selenium and arsenic. Arch. Microbiol. 171:19-30.

42. Switzer Blum, J., J. F. Stolz, A. Oren, and R. S. Oremland. 2001. Selenihalanaerobacter shriftii gen. nov., sp. nov., a halophilic anaerobe from Dead Sea sediments that respires selenate. Arch. Microbiol. 175:208-219.

43. Tomei, F. A., L. L. Barton, C. L. Lemanski, and T. G. Zocco. 1992. Reduction of selenate and selenite to elemental selenium by Wolinella succinogenes. Can. J. Microbiol. 38:1328-1333.

44. Wells, A. F. 1984. Structural inorganic chemistry, 5th ed., p. 699-747. Claredon Press, Oxford, United Kingdom. 